By FELIX E. HIRSCH

\title{
Why Special Collections in College Libraries?
}

Mr. Hirsch is librarian of Bard College. This paper was presented at the Conference of Eastern College Librarians, November 29, 1941 .

$\mathrm{W}$ HEN the new library building of Albion College in Michigan was dedicated in June 1938 Randolph G. Adams of the Clements Library in Ann Arbor gave a remarkable address, in which he stressed the need for special collections in college libraries. ${ }^{1}$ "It seems to me," he said, "that one of the neglected functions of the college library is to collect, to preserve, and to make available for properly qualified readers those unusual books which belong uniquely and appropriately to the community in which the college is located." And later, he stated in even more general terms that he thought it a particularly important function of a college library to be a local center of collecting and preserving unusual books. To live up to his own theories, he concluded his address by making the announcement that he had solicited from some leading antiquarian booksellers the gift of seventeen rarities bearing on the history of $\mathrm{Al}-$ bion College and the state of Michigan and on the development of printing since the days of the incunabula. The fact that the statement was not just made by an

1 Published in Albion College Bulletin 34: Aug. I 938 .

JUNE, 1942 ambitious college librarian but by the head of an outstanding research library, adds greatly to its weight. It may be taken as an invitation to consider here, in some detail, the problem of special collections in college libraries, particularly since this topic has not yet found in the professional literature the careful attention which it deserves. $^{2}$

When speaking here of the college library, I have not so much the big and well-endowed institution in mind. After all, the special collections of Williams and Dartmouth rank with those of the universities. I think chiefly of the small or medium sized college libraries, like Albion or Bard, with a small professional staff, with collections of fifty or sixty thousand volumes and with a book and periodical budget in the neighborhood of $\$ 4000$. The question is, how far do these smaller libraries need special collections in order to fulfill their educational function and how far can they afford administering them. Before arriving at any general conclusions, it seems desirable to examine the

\footnotetext{
2 There are only five important general references in recent years: Adams, $R$. G. "The Place of Rare Pooks in a College or University Library." College and Research Libraries $2: 27-32$, December I940; Elder, L. W. "Special Collections Pertinent to the College Library." Illinois Libraries I9:1 9-22, Decem. ber I 937; McCrum, B. P. An Estimate of Standaris for a College Library. Revised edition, I037; ; $4 \mathrm{I}-42$; Powell, L. C. "The Function of Rare Books." College and Research Libraries I:97-103, December I 939; Randall, W. M., and Goodrich, F. L. D. Principles of Collége Library Administration, p. I9I-99.
} 
various types of special collections as they are found in college libraries. ${ }^{3}$

There are three major types of special collections, not all alike in relevance for a college library. The first type would be the special collection that is related to the history of the institution and the founder's family, the religious and educational background of the college, and the geographical area in which it is located. The second type refers to the function of the library to promote the appreciation of books; these collections deal with the history and aesthetics of printing and binding. The third type is coordinated with the educational work of the college; these subject collections grow out of benefactions of friends of the college or out of the teaching and research of faculty members.

\section{Historical Collections}

There are quite a few collections of the historical type that combine local interest with high general significance. The large and rich collection that the library of Mount Holyoke has assembled on Mary Lyon, the founder of the college, has a meaning far beyond the campus of South Hadley. It bears on the whole early history of women's education in this country and offers sidelights also on social life in New England; some appreciation of its wealth may be gained from a study of A. C. Cole's colorful centennial history of the college. The same recognition is due to the Quaker Collection at Haverford, which has no rival in this country. Here many rare volumes from the earlier days of Quakerism, as well as the best of the

\footnotetext{
3 This rapid survey is based on experiences and observations made at Bard College Library and on in formation kindly furnished by the following librarians and curators: Fanny Borden, Vassar College; Thomas E. Drake, Haverford College; Flora B. Ludington, Mount Holyoke College; Th. E. Norton, Lafayette College: Edith Rowley, Allegheny College; N. Orwin Rush, Colby College.
}

later literature and also manuscript writings of individual Friends, have been gathered together. They are consulted not only by Haverfordians but also by outside students of Quakerism. In the opinion of the curator of the collection, Professor Thomas E. Drake, "Haverford profits from the fact that it is a recognized depository of the records of Quaker thought and a center for the study and exposition of the Quaker way of life."

Generous gifts have enabled Bard College Library in recent years also to develop a historical collection that may add to the usefulness of the library. This so-called Bardiana Collection deals chiefly with the history of the founder's family and with the early years of the college. ${ }^{4}$ The Bards were French Huguenots who came to this country early in the eighteenth century and rose rapidly to wealth and scholarly fame. The most renowned member of the family, Dr. Samuel Bard was one of the great figures in the early history of Columbia College and also a president of the College of Physicians and Surgeons. The Bards owned a large estate in the Hudson River Valley which was called Hyde Park; from that place the now so well-known town of Hyde Park derives its name. This collection of documents, letters, pictures, and books has, therefore, a meaning for the history of Columbia University as well as that of Dutchess County, in which the college is located, and has been used by scholars interested in either aspect. The varying displays of items from the collection have appealed to prominent outside visitors just as much as to neighbors in the county and to faithful alumni. Last but not least, they have made some of the students aware of the

4 This collection is described in the present writer's article on the Bard family, in Columbia University Quarterly 33:222-4 I, October r94 I. 
tradition to which the college is linked. Recently a special room was designed to house this collection adequately and there we are also placing the more valuable part of the personal library of the founder's family. From the educational aspect it has never seemed satisfactory to stress only the history of the Bard family. We have been trying to bring together also other materials that might be useful for students seriously interested in the Hudson River Valley and its problems. A faculty committee has just been appointed, of which a history professor experienced in regional studies is chairman and of which the librarian is also a member, in order to develop a suitable program of such studies. There are already a few senior projects along these lines and the committee hopes to stimulate more of them. As time goes on -and all these collections need very much time and loving attention-we will thus add to the original Bardiana Collection a working collection for educational purposes.

\section{Needs of Undergraduate Students}

This is a very important point, for in a college library one cannot only think in terms of advanced scholarship. We have to keep the needs of undergraduate students in mind and have to make the historical collection meaningful to themthat is, with the support of the experts on the faculty. Otherwise, we would fulfill the function of a museum instead of that of a college library. The reservation that students do not fully grasp the value of such collections has sometimes been made by librarians. Lucius W. Elder of Knox College states frankly: "Students go into the room of a special collection to study in quiet and leave the books therein to rot at their leisure." Professor Drake knows of undergraduates who remember the Quaker Alcove at Haverford "chiefly as a retreat from the scrutiny of the watchdogs of the library, where tired feet may be elevated above one's book as an aid to study or a preliminary to sleep." And the situation at Lafayette College leaves also something to be desired. In the course of a decade, a rich collection of books, pamphlets, manuscripts, etc., dealing with Lafayette's career and with the French participation in the American Revolution, has been built up there and made readily available to the public. However, the librarian, Mr. Norton, declares: "I am not satisfied with the use the books get. There is not likely to be any improvement or increase in the usefulness of the collection until we have on the college teaching staff in either French or history men who have a special interest in this subject."

\section{Educational Value of Rare Books}

The second type of special collections, as defined at the outset, is represented at Bard by a large group of books that was once exhibited under the title, "From Gutenberg to Goudy." It includes a leaf of the forty-two line Gutenberg Bible, some incunabula, a number of works printed by Aldus and Estienne, as well as famous works of later centuries, including some designed by masters of our own day, like Updike and Goudy. The majority of these items were given to the library long ago and were kept there under lock and key. Only a few years ago did we start to display them freely and to use them for the purpose of strengthening an understanding of the graphic arts among the students. That is an important function in a college in which the Fine Arts are a major field of study. This appreciation of fine printing has been deepened by lectures 
given in the library by men like $\mathrm{F}$. W. Goudy and Helmut Lehmann-Haupt. From my own observations, I would like to agree with Blanche $\mathrm{P}$. McCrum, librarian of Wellesley College, who, in her annual report for 1939-40, protested against the "unqualified assertion sometimes made that rare books are a drug on the college library market. So they are if treated as museum pieces; but when instructors and curators join hands in making them part of the bone and sinew of teaching and when they provide material for theses and for original study by students in advanced classes, they begin to make the rich contribution to the educational resources of the college planned" by the benefactors.

\section{Librarian and Collector}

Out of the efforts to evaluate and display the treasures of our two collections, the nucleus of a third collection was born. A neighbor of the college, himself a book collector of great distinction, gained confidence in the work of the Bard Library when he saw how the staff handled the other collections. He decided to present it with some samples of masterpieces of English literature of the nineteenth and twentieth centuries in order to give new inspiration to the study of English at Bard. The volumes and manuscripts he has donated from time to time are not many in number but they are among the choicest possessions we have. This friend of Bard Library started out with letting us have some precious Hardy items. Now he has presented us with Dickens' own autographed copy of the first edition of Nicholas Nickleby and with a set of original letters by Sir Walter Scott, in which the author gives advice to a young poet-in. deed a topic of interest to students. Other gifts along similar lines may follow. Even though this collection is small and does not aim by any means at completeness, it has its great value to the college community; for it does make a difference, at least to sensitive persons, whether they see a famous Hardy poem in a cheap edition or in the manuscript. The fact that this collection is being developed not by the initiative of some professor or librarian, but by a collector, should not be a reason for complaint. On the contrary, Randolph G. Adams, in his earlier mentioned address, blames librarians for having so little conception of the function of the collector. It secms to me that indeed we should try to gain their friendship and thoughtful advice without ever hunting for their possessions. We are librarians, not beggars!

\section{Relations with Collector}

This attitude is also the only fair one in dealing with the book collector who happens to be a member of the faculty. At Bard we have such a case. The professor of French, Artine Artinian, has brought together in many years of research what is probably the largest collection of Maupassant items in existence. We have been permitted to display the collection for a number of months and its existence on campus has created a sustained interest in Maupassant and all he stands for in French literature. Collections of similar quality may be found on quite a few campuses; they are always worthy of the librarian's appreciation and, if needed, his cooperation. In some instances, a professor who is advanced in years might even present his collection to the library of his college. Haverford College Library, to name just one, has the good fortune of falling heir to Rufus M. Jones' Collection on European mysticism. 
Another variety of a gift collection is happily represented at the library of Allegheny College in Pennsylvania. Three years ago, Ida M. Tarbell turned over her working collection on Abraham Lincoln to the library; this collection consists of all the materials that she used when writing her Lincoln book. Edith Rowley, the librarian, states that from the point of view of educational usefulness the collection is a decided addition to the resources of the library. The year Miss Tarbell presented the material she gave a month of lectures on biographic methods, using the Lincoln collection for illustrative purposes, and later the head of the history department gave a seminar course in the room now housing the collection. Three seniors used phases of Lincoln's life as the subject for their so-called comprehensive papers.

\section{Teaching and Collecting}

One group of what we called the subject collection is not yet found at Bard, due chiefly to the fact that the college in its present form is still very young. We do not possess any collection that has grown out of the actual teaching over a long period of years. Such collections will help the college library greatly in fulfilling its task. Here I think, for instance, of the Hardy Collection at Colby College, which is the work of Professor Carl J. Weber, who in fifteen years of passionate effort brought together a collection of unusual wealth and comprehensiveness. This collection has added greatly to the nationwide reputation of the college and its library, and without these materials Professor Weber certainly would not have written his recent Hardy biography. It is no wonder that the librarian of Colby College, N. Orwin Rush, is "fully convinced that a special collection, properly handled, is a great asset to a college library." Vassar College, to give another example of this type, possesses two important collections that were developed by faculty efforts. One is the famous Justice Collection of material relating to the periodical press. It was gathered together by the Vassar historian, Lucy M. Salmon, whose own widely-used books on newspaper problems were chiefly based on materials in this collection. This collection, by the way, is kept up through purchases from the income of a fund and through contributions of books, pamphlets, and clippings from alumnæ of the college; the collection is not segregated on the shelves. The other significant special collection at Vassar is devoted to Robert Owen. It includes books, pamphlets, and periodical articles by and about Robert Owen. The collection was established in connection with Professor Herbert Mills' seminar class in socialism about forty years ago and includes many important first editions and other rare items. Each year a few items are added.

\section{Administration of Collections}

The administration of such collections sometimes presents problems. Who shall have control and who is to do the actual work? In a small college it may seem preferable to center the special collections in the library and administrate them directly, of course with advice from interested faculty members. For the larger library more flexible arrangements may be wiser. At Vassar, for instance, the departments are entrusted with the care and building up of various special collections, but the librarian is entitled to exert as much supervision as she deems necessary. for the general good. 
The small and medium sized college will of necessity always try to keep the expense for special collections as far down as possible. I personally would not feel that I acted properly if I were spending large sums of our fairly limited library budget on our special collections. Here or there I buy an indispensable item for rounding out the Bardiana Collection but I certainly would think it outrageous to spend some hundreds of dollars for getting more incunabula. Other librarians feel the same way. Colby never spends more than $\$ 200$ a year for the Hardy Collection. Haverford tries to avoid the purchase of any very expensive Quaker item that would only duplicate material available in other libraries around Philadelphia. Even a rich college library like Vassar is very cautious in acquisitioning for its special collections. In most of these colleges there are usually some friends of the library, be they organized or unorganized, to whose loyalty and generosity the purchase of large items might be referred.

\section{Three Great Dangers}

After this brief survey of special collections, it will not be difficult to arrive now at some general conclusions. There are three great dangers apparent to the critical observer. Robert B. Downs, in his latest report on notable materials added to American libraries, ${ }^{5}$ complains justly about the scattering of complementary and supplementary materials in widely separate areas of the country. "In a nation," he says, "as vast as our own, there may well be room for duplication of collections even in highly specialized fields. But a reasonable degree of coordination is obviously desirable."

SDowns, Robert B. "Notable Materials Added to American Libraries, 1939-1940." Library Quarterly I1:257-30I, July 194I.
Another great danger is that a library may try to swallow more than it can chew. It is hazardous to accept a special collection if you have no proper place to house it, no decent cases in which to display some choice items, no money at all to keep it up, no faculty experts to organize and develop it, and no staff to catalog and supervise it. Adventures of this kind are almost inexcusable, for the acceptance of any largescale gift implies that you will treat it and make it available in an appropriate fashion.

The third and probably greatest danger is to have special collections for which there is no interest or need whatsoever on the college campus. It would seem fool ish to invest time and money on a collection that is not somehow related either to the traditions and the environment of the college, or to the history of bookmaking, or to the academic curriculum of the particular college, or to the scholarly interests of faculty members. Certainly it would be unwise for the average college library to take over a collection on, say, Arabic literature, if nobody on campus knows that language. No over-ambition, no competitive spirit, no desire for publicity, no personal vanity should ever induce a college librarian to acquire such a collection that would be deadwood in his library but might be an asset in a larger institution.

\section{A New Stimulus}

On the other hand, we should not forget that many of the special collections have a good reason for being. Of course, we regret the splitting up of materials that the scholar might like to examine at one place (even though in times of war this segregation of rarities may have obvious advantages). But we have also to keep in mind that many materials would never have become accessible to the public at all if the 
donor had not intended to do a particular library a favor. The gentleman who gave Bard his Hardy items would probably not have cared to turn them over to Colby College but might have kept them out of sight if he had not desired to do something constructive for Bard. Also it may be said that many special collections in college libraries do not duplicate at all the work of larger libraries. The college library that collects materials on the part of the country to which it belongs and on the history of its own institution may fulfill a unique task. Randolph G. Adams, for one, is convinced that no other type of library is more suited for it. But the most pertinent argument for special collections would be the fact that they may add greatly to the educational value and the scholarly rank of the library. Special collections may offer the students working tools that no textbook or monograph could ever provide. The best of these collections may instil in the student some lasting enthusiasm. They also may strengthen the ties that exist between faculty and library. They may make the professor and the library staff work more distinctly towards a. common goal.

Although we librarians are used to sigh about our being overburdened with work, it' should not be overlooked that special collections may offer us a new stimulus. We are members of a profession that is overwhelmed with routine duties. Would the cataloger who spends most of the time just handling Library of Congress cards not be happy to get an opportunity of doing some real cataloging of truly great books? Is this not also a chance for the circulation assistant, who hands out average books all day, suddenly to get excited about dealing with some real rarities of printing or binding? For the reference assistant to answer some more intricate bibliographical questions than those that usually come to his desk? As for the librarian himself, Lucius W. Elder has expressed the feelings of many of his colleagues in saying about these special collections: "When the librarian has accumulated a building full of such things and when he has found out what to do with them, he may then pride himself on having liquified one of the chief debts of the library to mankind." 